\title{
A Survey of Preference and Utilization of Drug Information Resources by Pharmacy Students
}

\author{
Bisrat Hailemeskel* Imbi Drame, Pawvana Pansiri and Min Choi
}

Howard University College of Pharmacy, Washington, Washington, DC, USA

\begin{abstract}
Having adequate drug information search skills is crucial in order for today's pharmacists to optimize pharmaceutical care. Howard University College of Pharmacy seeks to better prepare students for this skill by offering a core course entitled, "Drug Informatics". The purpose of this study was to evaluate the drug information search skills and preferences of the students using a questionnaire. A survey was designed with 18 questions and given to a sample of 65 pharmacy students in their $4^{\text {th }}$ professional year. Data was analyzed by using frequency and Chi square (SPSS) to determine the relationship between students' demographic and their drug information searching skill or preferences. Survey participation was $48 \%$ (31 of 65 ) with $42 \%$ male and $58 \%$ female. The most frequently used resources were online databases. Participants who were young or with BA/BS degrees appeared to search more frequently. Most drug information questions received were related to adverse drug events and drug identification. Most participants were confident in their retrieved information and searching skills. The results of this survey will help to improve the design of current drug information coursework.
\end{abstract}

Keywords: Drug information; Clinical pharmacy; Clinical practice; Internet as information source; E-health; Pharmaceutical care; Medicines management

\section{Introduction}

There exist various drug information resources with each containing its own unique features. Keeping up-with current and accurate drug information remains a great challenge for pharmacy students and healthcare professionals alike. Users need suitable search skills to retrieve accurate information in a timely manner. Howard University College of Pharmacy is one of a limited, but growing, number of pharmacy programs nationwide that has recognized the value of offering a drug informatics course to first year pharmacy students as core curriculum. This academic architecture is intended to foster foundational drug information searching abilities in students while nurturing an appreciation and understanding of the importance of developing such abilities early on.

The purpose of this study is to evaluate the drug information searching skills drug resource preferences and beliefs about drug information search skills held by students using a questionnaire.

Comparable studies have been published which utilized surveys to determine user preferences. A study was conducted by Hanrahan and Cole to determine the preferred modality by faculty and students to access desired drug information resources. A 39-item survey instrument was used. The study, which had a response rate of $81 \%$ $(n=289)$, indicated that laptop or desktop computers were the preferred platforms for accessing drug information [1].

A study conducted by Kupferberg and Hartel sought to determine variation in preferences of among pharmacy students, faculty, and medical librarians [2] based upon five different full-text databases. According to the authors, preferences were highly variable between groups. While librarians ranked DrugDex the highest, faculty members found Lexi-Drugs most useful,, and students favored eFacts. Both faculty and students found the PDR to be least useful, and librarians ranked AHFS the lowest. A similar study was done by Clauson et al to determine which online drug information databases were preferred to enhance clinical decision support [3]. According to the authors, results determined that preferences could be ranked from highest to lowest as follows: Clinical Pharmacology, Micromedex, Lexi-Comp Online, Facts \& Comparisons 4.0, Epocrates Online Premium, RxList, and Epocrates Online Free.

Unlike the aforementioned studies, this investigation focuses on preferences for both print and online drug information resources, including general search engines, used by survey participants (pharmacy students in their $4^{\text {th }}$ professional year who are actively participating in clinical rotations). As a secondary endpoint, this study investigates the correlation between certain demographic characteristics and the behaviors and beliefs surrounding searching ability.

\section{Methods}

A questionnaire was developed to investigate the beliefs surrounding the searching ability and resource preferences of the fourth-year pharmacy students enrolled in the College of Pharmacy at Howard University. The survey questionnaire consists of 18 questions to gather data about: demographics (age, gender, college education levels prior to entering pharmacy school and number of pharmacy working years); reference resources/search engines used; frequency of searching; website verification; preferred drug information sources, search time; confidence in retrieved information; and confidence in searching skill. Analysis of questionnaire data was performed using SPSS. Frequency and a Chi square analysis was use to establish a potential association

*Corresponding author: Bisrat Hailemeskel, Associate Professor and Co-Director for International Projects, Howard University College of Pharmacy, Clinical and Administrative Pharmacy Sciences, 2300, 4th Street, Washington, Washington, DC 20059, USA, Tel: 2028064214; E-mail: bhailemeskel@Howard.edu

Received November 24, 2015; Accepted August 06, 2016; Published August 13, 2016

Citation: Hailemeskel B, Drame I, Pansiri P, Choi M (2016) A Survey of Preference and Utilization of Drug Information Resources by Pharmacy Students. Adv Practice Nurs 2:122. doi: 10.4172/2573-0347.1000122

Copyright: ( 2016 Hailemeskel B, et al. This is an open-access article distributed under the terms of the Creative Commons Attribution License, which permits unrestricted use, distribution, and reproduction in any medium, provided the original author and source are credited. 
between the demographic factors and participants' rankings.

\section{Results}

Of the 65 questionnaires distributed, 31 (48\%) were completed and returned. There were more female $(57.7 \%)$ than male $(42.3 \%)$ participants. Most participants were between 20 and 29 years of age. When asked about prior education, $64.3 \%$ of survey participants reported that they had earned a bachelor of arts (BA) or science (BS) degree prior to entering the pharmacy program $28.6 \%$ had received an associates (AA) degree and $3.6 \%$ had received a master of arts (MA) or science (MS).

Participants were asked to indicate the reference resources that they normally use when they need drug or health-related information. Participants were presented with 5 reference categories: (1) Google or other general search engines, (2) Textbook or journal, (3) Package insert, (4) Subscription-based databases and (5) other resource type.

As shown in Table 1, Google or other search engines were reported to be the most used references by $80 \%$ of participants. On the other hand, textbooks and journals were used the least, ranked most used by only $17 \%$ of participants. Out of the five categories of search engines presented in the question are participants were asked to indicate which one they normally use to look up drug or health information. These search engines included: Google, Yahoo, Bing, and Ask MSN. Ninetythree percent of the participants reported that Google was their most used search engine. About $80 \%$ of these participants indicated that they had never used other search engines such as Bing, Ask on MSN, or Yahoo to look up drug or health information (Table 2).

There was a significant association between level of education and having a preference for Google or other general internet search engines $(p=0.000)$. Eighty three percent participants with a BA or BS degree would mostly likely prefer to use Google or other general internet search engine.

Survey participants were asked the frequency with which they researched health,/medical, or drug-related topics either for personal use or for the purpose of patient care while on a clinical rotation. They were presented with five frequency categories: multiple times a day, once a day, once a week, once a month and once in a while. The vast majority (69\%) of participants responded that they searched multiple times a day, followed by search once a day reported by $13.8 \%$ of participants (Tables 3 and 4). There were no associations found between frequency

\begin{tabular}{|l|c|c|c|c|}
\hline References & $\begin{array}{c}\text { Most Used } \\
(\mathbf{\%})\end{array}$ & $\begin{array}{c}\text { Occasionally } \\
\text { Used (\%) }\end{array}$ & $\begin{array}{c}\text { Least Used } \\
\mathbf{( \% )}\end{array}$ & $\begin{array}{c}\text { Never Used } \\
\text { (\%) }\end{array}$ \\
\hline $\begin{array}{l}\text { Google/Other Search } \\
\text { Engine }\end{array}$ & 80 & 13.3 & 6.7 & 0 \\
\hline Textbooks/Journal & 16.7 & 43.3 & 26.7 & 13.3 \\
\hline Package Insert & 23.3 & 43.3 & 16.7 & 13.3 \\
\hline $\begin{array}{l}\text { Subscription Based } \\
\text { Database }\end{array}$ & 42.9 & 28.6 & 17.9 & 10.7 \\
\hline Others & 40 & 40 & 0 & 20 \\
\hline
\end{tabular}

Table 1: Reference resource preferred by fourth year pharmacy students.

\begin{tabular}{|l|c|c|c|c|}
\hline $\begin{array}{l}\text { Search } \\
\text { Engines }\end{array}$ & $\begin{array}{c}\text { Most Used } \\
(\mathbf{\%})\end{array}$ & $\begin{array}{c}\text { Occasionally } \\
\text { Used (\%) }\end{array}$ & $\begin{array}{c}\text { Least Used } \\
(\mathbf{\%})\end{array}$ & $\begin{array}{c}\text { Never Used } \\
(\mathbf{\%})\end{array}$ \\
\hline Google & 93.3 & 6.7 & 0 & 0 \\
\hline Yahoo & 3.6 & 3.6 & 14.3 & 78.6 \\
\hline Bing & 0 & 7.1 & 7.1 & 85.7 \\
\hline Ask/MSN & 0 & 3.6 & 14.3 & 82.1 \\
\hline Others & 21.4 & 14.3 & 0 & 64.3 \\
\hline
\end{tabular}

Table 2: Search engine preferred by fourth year pharmacy students.

\begin{tabular}{|l|c|c|c|c|c|}
\hline & $\begin{array}{c}\text { Multiple } \\
\text { times a day }\end{array}$ & $\begin{array}{c}\text { Once a } \\
\text { day }\end{array}$ & $\begin{array}{c}\text { Once a } \\
\text { week }\end{array}$ & $\begin{array}{c}\text { Once a } \\
\text { month }\end{array}$ & $\begin{array}{c}\text { Once in a } \\
\text { while }\end{array}$ \\
\hline $\begin{array}{l}\text { Number of } \\
\text { students (\%) }\end{array}$ & $20(69 \%)$ & $4(13.8 \%)$ & $2(6.9 \%)$ & $1(3.4 \%)$ & $2(6.9 \%)$ \\
\hline
\end{tabular}

Table 3: Frequency of Drug Information Research by fourth year pharmacy students.

\begin{tabular}{|c|c|c|c|c|c|}
\hline & $\begin{array}{c}\text { Multiple times a } \\
\text { day (\%) }\end{array}$ & $\begin{array}{c}\text { Once a day } \\
(\%)\end{array}$ & $\begin{array}{c}\text { Once a } \\
\text { week (\%) }\end{array}$ & $\begin{array}{c}\text { Once a } \\
\text { month (\%) }\end{array}$ & $\begin{array}{l}\text { Once in a } \\
\text { while (\%) }\end{array}$ \\
\hline \multicolumn{6}{|c|}{ Age range(year) } \\
\hline $20-29$ & 70.0 & 66.7 & 50.0 & 100.0 & 50.0 \\
\hline $30-39$ & 20.0 & 33.3 & 50.0 & 0 & 50.0 \\
\hline $40-49$ & 5.6 & 0 & 0 & 0 & 0 \\
\hline$\geq 50$ & 0 & 0 & 50.0 & 0 & 0 \\
\hline \multicolumn{6}{|l|}{ Gender } \\
\hline Males & 31.2 & 50.0 & 100.0 & 100.0 & 50.0 \\
\hline Females & 68.8 & 50.0 & 0 & 0 & 50.0 \\
\hline \multicolumn{6}{|l|}{$\begin{array}{l}\text { College } \\
\text { education }\end{array}$} \\
\hline Associate & 27.8 & 33.3 & 0 & 100.0 & 50.0 \\
\hline $\mathrm{BA} / \mathrm{BSc}$ & 66.7 & 66.7 & 50.0 & 0 & 50.0 \\
\hline $\mathrm{MS} / \mathrm{MA}$ & 5.6 & 0 & 0 & 0 & 0 \\
\hline \multicolumn{6}{|l|}{ Ph.D } \\
\hline \multicolumn{6}{|c|}{ Number of pharmacy working years } \\
\hline$<2$ & 45.0 & 0 & 100.0 & 100.0 & 100.0 \\
\hline $2-4$ & 40.0 & 50.0 & 0 & 0 & 0 \\
\hline $5-6$ & 15.0 & 0 & 0 & 0 & 0 \\
\hline $7-9$ & 0 & 25.0 & 0 & 0 & 0 \\
\hline$>9$ & 0 & 25.0 & 0 & 0 & 0 \\
\hline
\end{tabular}

Table 4: Relationship between demographic factors (age, gender, college education and number of pharmacy working years) and the frequency of research for drug information by fourth year pharmacy students.

of conducting a search and demographic factors, such as age, gender, college education level, and number of pharmacy working years).

Frequency of use of 5 different types of subscription-based drug references was determined with the survey. The types included both electronic and print sources: Drug Facts and Comparisons; AHFS Drug Information; Micromedex and/or Clinical Pharmacology; Physician's Desk Reference (PDR); and Other subscription-based drug reference. Eighty-one percent of the participants ranked Micromedex and/or Clinical Pharmacology as their most used subscription-based drug information sources in the past two years. Twenty percent of the participants ranked other subscription-based drug information as their secondary preference. Lexicomp and UpToDate were mentioned by participants in the "other" category (Table 5).

Fifty- two percent of the participants indicated that they always verify the websites or check the sponsors when they obtain information using a search engine, followed by $42 \%$ of the participants who indicated they verify the websites only sometimes (Table 6).

Table 7 illustrates the association between age and the frequency of verifying the authenticity of drug information websites before using them $(\mathrm{p}=0.005)$. Eighty percent of participants who indicated that they always verify the authenticity of the websites were in the 2029 years group. Additionally, there was a strong association between the frequency of verifying the authenticity of these websites and the participant's level of education. About $77 \%$ of participants who always verify the authenticity of the websites have BA or BS degree

When asked about the most common reason for conducting a drug information search, $83 \%$ of participants chose adverse drug events or side effects as the most frequent reason, followed by indication use 


\begin{tabular}{|l|c|c|c|c|}
\hline $\begin{array}{l}\text { Subscription } \\
\text { based reference }\end{array}$ & $\begin{array}{c}\text { Most Used } \\
\text { (\%) }\end{array}$ & $\begin{array}{c}\text { Occasionally } \\
\text { Used (\%) }\end{array}$ & $\begin{array}{c}\text { Least Used } \\
(\%)\end{array}$ & $\begin{array}{c}\text { Never Used } \\
(\%)\end{array}$ \\
\hline $\begin{array}{l}\text { Drug Fact and } \\
\text { Comparison }\end{array}$ & 6.9 & 20.7 & 24.1 & 48.3 \\
\hline $\begin{array}{l}\text { AHFS Drug } \\
\text { Information }\end{array}$ & 0 & 15.4 & 23.1 & 61.5 \\
\hline $\begin{array}{l}\text { Micromedex/Clinical } \\
\text { Pharmacy }\end{array}$ & 80.6 & 9.7 & 3.2 & 6.5 \\
\hline $\begin{array}{l}\text { Physician Desk } \\
\text { Reference }\end{array}$ & 0 & 11.1 & 22.2 & 66.7 \\
\hline Others & 20.0 & 30.0 & 20.0 & 30.0 \\
\hline
\end{tabular}

Table 5: Frequency of subscription based drug information reference use by fourth year pharmacy students (in the past 2 years).

\begin{tabular}{|l|c|c|c|}
\hline & $\begin{array}{c}\text { Always } \\
(\%)\end{array}$ & $\begin{array}{c}\text { Sometimes } \\
(\mathbf{\%})\end{array}$ & $\begin{array}{c}\text { Never/l do not remember } \\
(\mathbf{\%})\end{array}$ \\
\hline $\begin{array}{l}\text { Number of participants } \\
(\%)\end{array}$ & $16(51.6)$ & $13(41.9)$ & $2(6.5)$ \\
\hline
\end{tabular}

Table 6: frequency of verifying the authenticity of websites/checking the sponsors before using the information by fourth year pharmacy students.

\begin{tabular}{|c|c|c|c|}
\hline Age range(year) & $\begin{array}{l}\text { Always } \\
(\%)\end{array}$ & $\begin{array}{c}\text { Sometimes } \\
(\%)\end{array}$ & $\begin{array}{l}\text { Never/l do not } \\
\text { remember (\%) }\end{array}$ \\
\hline $20-29$ & 80.0 & 53.8 & 0 \\
\hline $30-39$ & 20.0 & 38.5 & 50.0 \\
\hline $40-49$ & 0 & 0 & 50.0 \\
\hline$\geq 50$ & 0 & 7.7 & 0 \\
\hline \multicolumn{4}{|l|}{ Gender } \\
\hline Males & 40.0 & 40.0 & 100.0 \\
\hline Females & 60.0 & 60.0 & 0 \\
\hline \multicolumn{4}{|l|}{ College education } \\
\hline Associate & 23.1 & 38.5 & 0 \\
\hline $\mathrm{BA} / \mathrm{BSc}$ & 76.9 & 61.5 & 0 \\
\hline MS/MA & 0 & 0 & 50.0 \\
\hline Ph.D & 0 & 0 & 50.0 \\
\hline \multicolumn{4}{|c|}{$\begin{array}{l}\text { Number of pharmacy } \\
\text { working years }\end{array}$} \\
\hline$<2$ & 40.0 & 46.2 & 100.0 \\
\hline $2-4$ & 33.3 & 38.5 & 0 \\
\hline $5-6$ & 20.0 & 7.7 & 0 \\
\hline $7-9$ & 0 & 7.7 & 0 \\
\hline$>9$ & 6.7 & 0 & 0 \\
\hline
\end{tabular}

Table 7: Relationship between demographic factors (age, gender, college education and number of pharmacy working years) and verifying the authentic of websites by fourth year pharmacy students.

(69\%), and dosage/administration (69\%). The fourth rankings in this category are dosage/administration (20\%) (Table 8).

Chi square analysis was used to match survey results by demographic factors, which included age, gender, college education level and number of pharmacy working years. Results revealed significant associations between age and reason for searching, as well as between level of education and reason for searching. Younger participants, those in the 20-29 age group, were most likely to conduct a search in order to identify a drug product or it use $(68 \%)$. Those with BA or BS sited determining adverse drug event profile as being their most common reason for searching $(68 \%)$.

Participants were also asked to identify their preferred online reference used when they received specific questions related to an adverse drug effect. Half of all participants chose package insert. The other half chose other references such as Micromedex, UpTodate, Clinical Pharmacology and Epocrates, as their most frequently used references (Table 9).

\begin{tabular}{|l|c|c|c|c|}
\hline & $\begin{array}{c}\text { Most } \\
\text { Used }\end{array}$ & $\begin{array}{c}\text { Occasionally } \\
\text { Used }\end{array}$ & $\begin{array}{c}\text { Least } \\
\text { Used }\end{array}$ & Never Used \\
\hline Drug identification & 34.5 & 31.0 & 27.6 & 6.9 \\
\hline Indication/Use & 69.0 & 24.1 & 3.4 & 3.4 \\
\hline $\begin{array}{l}\text { Adverse drug events/ } \\
\text { side effects }\end{array}$ & 82.8 & 13.8 & 0 & 3.4 \\
\hline Dosage/administration & 69.0 & 24.1 & 3.4 & 3.4 \\
\hline Others & 20.0 & 20.0 & 0 & 60.0 \\
\hline
\end{tabular}

Table 8: Frequency of specific drug information needs by fourth year pharmacy students.

\begin{tabular}{|l|c|c|c|c|}
\hline & $\begin{array}{c}\text { Most } \\
\text { Used }\end{array}$ & $\begin{array}{c}\text { Occasionally } \\
\text { Used }\end{array}$ & $\begin{array}{c}\text { Least } \\
\text { Used }\end{array}$ & Never Used \\
\hline $\begin{array}{l}\text { Google or general } \\
\text { internet search }\end{array}$ & 46.7 & 20.0 & 30.0 & 3.3 \\
\hline Package insert & 50.0 & 33.3 & 6.7 & 10.0 \\
\hline $\begin{array}{l}\text { Resources available } \\
\text { through your company }\end{array}$ & 44.8 & 31.0 & 6.9 & 17.2 \\
\hline $\begin{array}{l}\text { Textbook such as } \\
\text { F\&C, PDR,etc }\end{array}$ & 3.6 & 25.0 & 28.6 & 42.9 \\
\hline Others & 50.0 & 0 & 20.0 & 30.0 \\
\hline
\end{tabular}

Table 9: Frequency of reference for research potential drug adverse effects by fourth year pharmacy students.

Participants ranked five databases that they would prefer to use to identify tablets or capsules by their shape, imprint, or color, including Google or other general internet search engines, drug identification databases, such as Identidex or Drug-Reax, and the dispensing system at work. Sixty-four percent selected "other," under whichMicromedex, Clinical Pharmacy, Lexicomp, Drugs.com, and Epocrates could be selected. Results revealed that the majority of survey participant preferred Google or other general internet search engine (54\%), followed by Identidex (31\%). No demographic factors were found to be associated with the reference usage for identifying the tablet (Table 10).

Regarding the a preferred resource for answering questions related to a US equivalent drugs marketed in foreign countries, $68 \%$ selected Google or other search engines, followed by Martindale: The Extra Pharmacopoeia (13\%). Those participants who had fewer years of pharmacy experience (those with 2-6 years of experience) preferred Martindale $(\mathrm{p}=0.046)$ and Drug Facts and Comparisons $(\mathrm{p}=0.047)$ (Tables 11 and 12).

When asked about how frequently they cross-checked preliminary search results using secondary resources before applying the information,) the majority of participants indicated that they that check "mostly" (39\%), while $29 \%$ cross-checked "occasionally". There was an association between gender and cross-checking the results. Ninety-one percent of female participants mentioned that they always cross-check versus only $9 \%$ for males $(\mathrm{p}=0.030)$. (Table 13 ).

The vast majority of survey participants received drug information questions only a few times a day (52\%), while $29 \%$ received questions once in a while and $16 \%$ received questions multiple times a day (Tables 14 and 15). However, when asked about average time spent researching a response to a drug information question, the majority of participants (45\%) chose 6-10 minutes, followed by 1-5 minutes (19\%). About one quarter of responders spent $>11$ minutes researching, drug information question (Tables 16 and 17).

The amount of time spent researching a drug information question had a significant association with educational attainment. Eighty-three percent of respondents who spent less time (1-5 minutes) researching requested drug information held a BA or BS, while two-thirds of 
Citation: Hailemeskel B, Drame I, Pansiri P, Choi M (2016) A Survey of Preference and Utilization of Drug Information Resources by Pharmacy Students. Adv Practice Nurs 2:122. doi: 10.4172/2573-0347.1000122

Page 4 of 6

\begin{tabular}{|l|c|c|c|c|}
\hline & $\begin{array}{c}\text { Most Used } \\
(\mathbf{\%})\end{array}$ & $\begin{array}{c}\text { Occasionally Used } \\
(\mathbf{\%})\end{array}$ & $\begin{array}{c}\text { Least Used } \\
(\mathbf{\%})\end{array}$ & $\begin{array}{c}\text { Never Used } \\
(\%)\end{array}$ \\
\hline $\begin{array}{l}\text { Google/ } \\
\text { general } \\
\text { internet } \\
\text { search }\end{array}$ & 53.8 & 7.7 & 7.7 & 30.8 \\
\hline Identidex & 30.8 & 23.1 & 11.5 & 34.6 \\
\hline $\begin{array}{l}\text { Drug-Reac } \\
\text { The } \\
\text { dispensing } \\
\text { system at } \\
\text { work }\end{array}$ & 4.2 & 25 & 16.7 & 54.2 \\
\hline Others & 11.5 & 23.1 & 19.2 & 46.2 \\
\hline
\end{tabular}

Table 10: Frequency of reference for identifying a tablet by its shape, imprint or color by fourth year pharmacy students.

\begin{tabular}{|l|c|c|c|c|}
\hline & Most Used (\%) & $\begin{array}{c}\text { Occasionally } \\
\text { Used (\%) }\end{array}$ & $\begin{array}{c}\text { Least Used } \\
(\mathbf{\%})\end{array}$ & $\begin{array}{c}\text { Never Used } \\
\text { (\%) }\end{array}$ \\
\hline $\begin{array}{l}\text { Google/ } \\
\text { general } \\
\text { internet search }\end{array}$ & 67.9 & 3.6 & 3.6 & 25.0 \\
\hline Martindale & 21.4 & 14.3 & 10.7 & 53.6 \\
\hline $\begin{array}{l}\text { Drug } \\
\text { Facts and } \\
\text { Comparisons }\end{array}$ & 8.0 & 8.0 & 12.0 & 72.0 \\
\hline $\begin{array}{l}\text { Index } \\
\text { Nominum }\end{array}$ & 8.0 & 8.0 & 20.0 & 64.0 \\
\hline Others & 22.0 & 0 & 22.0 & 55.6 \\
\hline
\end{tabular}

Table 11: Frequency of references for finding a US equivalent drugs by fourth year pharmacy students.

\begin{tabular}{|l|l|l|l|l|}
\hline & Always & Mostly & Occasionally & rarely \\
\hline Number of participants (\%) & $12(38.7)$ & $9(29.0)$ & $8(25.8)$ & $2(6.5)$ \\
\hline
\end{tabular}

Table 12: Frequency of cross-checking the results obtained with other resources before using the information by fourth year pharmacy students.

\begin{tabular}{|l|l|l|l|l|}
\hline Gender & Always & Mostly & Occasionally & rarely \\
\hline Males (\%) & 9.1 & 71.4 & 66.7 & 50.0 \\
\hline Females (\%) & 90.9 & 28.6 & 23.3 & 50.0 \\
\hline
\end{tabular}

Table 13: Frequency of cross-checking the results obtained with other resources before using the information by gender for fourth year pharmacy students.

\begin{tabular}{|l|c|c|c|c|}
\hline & $\begin{array}{c}\text { Multiple times } \\
\text { a day }\end{array}$ & $\begin{array}{c}\text { A few times } \\
\text { a day }\end{array}$ & $\begin{array}{c}\text { Once in a } \\
\text { while }\end{array}$ & Rarely \\
\hline Number of students (\%) & $5(16.1 \%)$ & $16(51.6 \%)$ & $9(29.0 \%)$ & $1(3.2 \%)$ \\
\hline
\end{tabular}

Table 14: Frequency of receiving drug related requests from patients that required the students to look up information.

\begin{tabular}{|l|l|l|l|l|l|}
\hline & $\begin{array}{l}\mathbf{1 - 5} \\
\text { minutes }\end{array}$ & $\begin{array}{l}\mathbf{6 - 1 0} \\
\text { minutes }\end{array}$ & $\begin{array}{l}\mathbf{1 1 - 1 5} \\
\text { minutes }\end{array}$ & $\begin{array}{l}\mathbf{1 6 - 2 0} \\
\text { minutes }\end{array}$ & $\begin{array}{l}\mathbf{2 1} \\
\text { minutes }\end{array}$ \\
\hline $\begin{array}{l}\text { Number of } \\
\text { student }(\%)\end{array}$ & $6(19.4 \%)$ & $14(45.2 \%)$ & $4(12.9 \%)$ & $4(12.9 \%)$ & $3(9.7 \%)$ \\
\hline
\end{tabular}

Table 15: Frequency of the duration of time spent processing/researching drug information questions per request by pharmacy students.

\begin{tabular}{|l|c|c|c|c|c|}
\hline & $\begin{array}{c}\mathbf{1 - 5} \\
\text { minutes }\end{array}$ & $\begin{array}{c}\mathbf{6 - 1 0} \\
\text { minutes }\end{array}$ & $\begin{array}{c}\mathbf{1 1 - 1 5} \\
\text { minutes }\end{array}$ & $\begin{array}{c}\mathbf{1 6 - 2 0} \\
\text { minutes }\end{array}$ & $\begin{array}{c}\mathbf{2 1} \\
\text { minutes }\end{array}$ \\
\hline $\begin{array}{l}\text { College } \\
\text { education }\end{array}$ & & & & & \\
\hline Associate & 16.7 & 46.2 & 33.3 & 0 & 0 \\
\hline BA/BSc & 83.3 & 53.8 & 66.7 & 33.3 & 0 \\
\hline MS/MA & 0 & 0 & 0 & 33.3 & 0 \\
\hline Ph.D & 0 & 0 & 0 & 33.3 & 0 \\
\hline
\end{tabular}

Table 16: Frequency of the duration of time spent processing/researching drug information questions per request by college education of pharmacy students. respondents who spent more time (16-20 minutes) held a graduate degree (MA, MS or $\mathrm{PhD})(\mathrm{p}=0.041)$ (Table 18).

The investigation found that a large majority (65\%) of survey participants were "confident" regarding the accuracy of the information that they retrieve from drug information searches, followed by $29 \%$ of participants who were "very confident". The majority $(89 \%)$ of participants in the 20-29 age group were very confident $(\mathrm{p}=0.005)$. Similar results were found when confidence in search skills was investigated. The majority of participants (48\%) were confident in their skill level, while about $23 \%$ were very confident.

\section{Discussion}

The purpose of this study was to determine preferences for commonly used drug information resources amongst $4^{\text {th }}$-year pharmacy students. The eventual goal is to use this data gathered from this investigation to modify the drug information course which is currently offered to first year students. The survey had a response rate of $48 \%$. Despite the availability of numerous well-referenced drug information resources, about $80 \%$ of participants identified Google or other search engines as their preferred choice, followed by subscription-based databases (43\%). Print textbooks and journals were the least utilized resources (17\%). These results may reflect the generational leanings and preferences of millennials, who strongly favor the rapid nature of the internet. Textbooks in electronic format were selected by some participants, suggesting that text is still widely used, but that the electronic format is preferred over print.

\begin{tabular}{|l|c|c|c|c|}
\hline & Very confident & Confident & $\begin{array}{c}\text { Somewhat } \\
\text { confident }\end{array}$ & $\begin{array}{c}\text { Less } \\
\text { confident }\end{array}$ \\
\hline $\begin{array}{l}\text { Number of } \\
\text { participants (\%) }\end{array}$ & $9(29.0)$ & $20(64.5)$ & $2(6.5)$ & 0 \\
\hline
\end{tabular}

Table 17: Confidence level of the accuracy of the retrieved information of fourth year pharmacy students.

\begin{tabular}{|l|l|l|l|l|}
\hline & \multicolumn{1}{|c|}{$\begin{array}{c}\text { Very } \\
\text { confident (\%) }\end{array}$} & $\begin{array}{c}\text { Confident } \\
\text { (\%) }\end{array}$ & $\begin{array}{c}\text { Somewhat } \\
\text { confident (\%) }\end{array}$ & $\begin{array}{c}\text { Less } \\
\text { confident (\%) }\end{array}$ \\
\hline Age range(year) & \multicolumn{5}{|c|}{} & \\
\hline $20-29$ & 88.9 & 57.9 & 0 & 0 \\
\hline $30-39$ & 11.1 & 36.8 & 50.0 & 0 \\
\hline $40-49$ & 0 & 5.3 & 0 & 0 \\
\hline$\geq 50$ & 0 & 0 & 50 & 0 \\
\hline Gender & & & & \\
\hline Males & 14.3 & 50.0 & 100.0 & 0 \\
\hline Females & 85.7 & 50.0 & 0 & 0 \\
\hline College education & & & & \\
\hline Associate & 14.3 & 31.6 & 50.0 & 0 \\
\hline BA/BSc & 85.7 & 63.2 & 0 & 0 \\
\hline MS/MA & 0 & 5.3 & 0 & 0 \\
\hline Ph.D & 0 & 0 & 50.0 & 0 \\
\hline Number of pharmacy & working years & & \\
\hline <2 & 37.5 & 45.0 & 100.0 & 0 \\
\hline 2-4 & 37.5 & 35.0 & 0 & 0 \\
\hline $5-6$ & 25 & 10 & 0 & 0 \\
\hline $7-9$ & 0 & 5.0 & 0 & 0 \\
\hline$>9$ & 0 & 5 & 0 & 0 \\
\hline
\end{tabular}

Table 18: Frequency of confidence level regarding the accuracy of the retrieved information by fourth year pharmacy students.

\begin{tabular}{|l|c|c|c|c|}
\hline & $\begin{array}{c}\text { Very } \\
\text { confident }\end{array}$ & Confident & $\begin{array}{c}\text { Somewhat } \\
\text { confident }\end{array}$ & $\begin{array}{c}\text { Less } \\
\text { confident }\end{array}$ \\
\hline Number of students (\%) & $7(22.6 \%)$ & $15(48.4 \%)$ & $9(29.0 \%)$ & 0 \\
\hline
\end{tabular}

Table 19: Confidence level of students in drug information searching skill. 
Among the search engines, this study showed that Google was the most preferred drug information resource. This result is reflected of more widely accepted data about the popularity of search engines by the public. According to the ranking published in September 2015 by eBizMBA, the estimated visitors for Google, Bing, Yahoo and Ask were $1.1,0.35,0.3$ and 0.3 billion respectively [4]. It would be reasonable to assume that similar use these search engines would be reflected in a smaller sample for the purpose of looking up health or drug information

Almost 70\% of participants search the internet for drug or health related information multiple times a day, and there was an association between certain demographic factors investigated in this study and the frequency of searching for drug information. The youngest group (70\%), female participants (69\%), those with BA or BS, and those with least number of pharmacy working years search more frequently comparing to their counterparts.

According to the publication by Larner AJ, the frequency of searching in a younger cohort was higher than an older age group [5]. The researchers in this study used a questionnaire administered to patients referred to a neurology outpatient department for threemonth periods during five consecutive years (2001-05). In a cohort of over 1000 patients, $40 \%$ reported home access to the Internet, and $11 \%$ had undertaken searches for medical information prior to clinic attendance. The frequency of internet searches was consistent over time and consistent amongst males and females, but varied by patient age, being higher in the younger age groups. According to a study conducted by Krieger, there was also an association between gender and access to a computer. Females were less like to have time for searching than males [6]. The preference for more frequent searches amongst younger users is consistent with results of our study. However, because study populations are different (students $v s$. patients), results may not necessarily support the findings our study. Also, the concept of access to computers may be an important confounder not accounted for in our study, and which may have resulted in differences in search frequency between males and females, as indicated by the Krieger study (Table 19).

Other demographic factors seemed to affect search preferences. In our study, having a college degree resulted in increased search frequency compared to those with no prior degree. On the other hand, there is an inverse relationship between search frequency and number of working years.

Although in our study, Micromedex/Clinical Pharmacology were the most popular subscription-based drug information resource, the finding of the study by Mountford et al. reflected different results [7]. In their study, Clinical Pharmacology, Micromedex, and Lexicomp were compared. Twenty-six pharmacists were sampled across several hospitals in Canada. Lexicomp was most popular and Micromedex was least popular. In our study, the reverse was true. This may be due to differences in the demographic characteristics between study participants. Other studies may be needed to substantiate the findings.

It is well-known that credible health and drug information contributes to optimal therapy to patients. The results of this study suggest that only one half of participants always verify the authenticity of the websites or sponsors. The majority of participants who said always verified the websites were those in the 20-39 age group and those with a BA or BS. Further study to discover what barriers cause the lack of authenticity verification, especially in those with higher college educational attainment is recommended.

The study found that the most common reason for looking up information is related to adverse drug events $(83 \%)$, indication or use (69\%), dosage and administration (69\%) and drug identification (34\%).

Product information leaflets or package inserts were preferred when answering patient questions related to a potential adverse drug effects. Package inserts are required as a part of FDA rules when a drug is marketed. Future intervention should be implemented to promote the use of other useful updated databases to supplement information found in package inserts or for use when package inserts are not available to the user.

Reputable subscription databases such as Micromedex, Clinical Pharmacology, Drugs.com, Epocrates, and Lexicomp were ranked highest for identifying tables or capsules by their shapes, imprints or colors. However, Google or other general internet search engines were also ranked highly by survey participants. Google or other general internet search engines were also most preferred for finding a US equivalent of foreign drugs. This high preference for Google across the spectrum of drug information search types raises concern as to whether the information commonly obtained by students on rotation is accurate enough to provide appropriate patient counselling on medication unless verified by other evidence-based references. Additionally, about twothirds of participants admitted that they do not cross-check the results obtained from initial drug information searches with a secondary resource before using the information. This raises further concern about credibility and accuracy of the information provided to patients. Mailed were particularly unlikely to institute cross-checking measures. Therefore, male pharmacy students may be a population that should be targeted for study and intervention in this area.

About one half of the participants received requests from patients to look up the information for them. This finding suggested that patients relied on the information provided by pharmacists and thus searching skill is essential for pharmacists to optimize patient care and satisfaction. Six to ten minutes seems the average time spent by most participants on a drug information question. Most participants that spent shorter time (5-10 minutes) were those who have a BA or BS degree. Interestingly, the participants having higher education than a bachelor's degree spent longer time searching for requested drug information. This finding may correlate strongly with findings about participant confidence. Overall, participants felt confident about their search skills. However, younger participants were most likely to feel confident. Findings about time spent researching questions and confidence about results found, may indicate that maturity, suggested by higher education and older age, may increase the level of self-awareness about one's true level of skill. In order to stay abreast of the current, credible, and accurate drug information, search skills are extremely essential for every pharmacist, regardless of demographic. Having such a confidence in the information obtain is also important, as this will likely promote more effective patient counselling However, further study is needed to verify the accuracy of the search results amongst $4^{\text {th }}$ year pharmacy students, and factors that affect certain behaviours surrounding drug information searching, such as cross-checking, and resource selection.

\section{Conclusion}

This survey addressed questions related to resource preferences, information searching frequency, searching ability, information types and beliefs about credibility of retrieved information. Participants' appeared to favor online search engines and databases, especially Google. Participants that searched most frequently and spent least searching time were most likely to have a bachelor's degree. Drug information questions related to adverse drug event/side effect 
Citation: Hailemeskel B, Drame I, Pansiri P, Choi M (2016) A Survey of Preference and Utilization of Drug Information Resources by Pharmacy Students. Adv Practice Nurs 2:122. doi: 10.4172/2573-0347.1000122

Page 6 of 6

appeared to be the most received types. Cross-checking was most likely to occur at the hands of women, and most participants were confident in the accuracy of their retrieved information and their searching skills. Younger participants were most likely to be confident in their skills and the information retrieved.

The data collected in this study implore further investigation of factors that influence drug information searching behaviours and preferences. Combining the results suggestive of demographic associations with such behaviours and preferences with other available data about best practices will lead to effective interventions that can be incorporated into drug information course design.

\section{References}

1. Hanrahan CT, Cole SW (2014) Assessment of drug information resource preferences of pharmacy students and faculty. J Med Libr Assoc 102: 117-121.

2. Kupfeberg N, Hartel LJ (2004) Evaluation of five full-text drug databases by pharmacy students, faculty, and librarians: do the groups agree? J Med Libr Assoc 92: 66-71.

3. Clauson KA, Marsh WA, Polen HH, Seamon MJ, Ortiz BI (2007) Clinical decision support tools: analysis of online drug information databases. BMC Med Inform Decis Mak 7: 7.

4. (2015) Top 15 Most Popular search Engines/September 2015.

5. Larner AJ (2006) Searching the Internet for medical information: frequency over time and by age and gender in an outpatient population in the UK. J Telemed Telecare 12: 186-188.

6. Lorence D, Park H (2007) Gender and Online Health Information: a partitioned technology assessment. Health Info Libr J 243: 204-209.

7. Mountford CM, Lee T, De Lemos J, Lowen PS (2010) Quality and Usability of Common Drug Information Databases. Can J Hosp Pharm 63: 130-137.

8. Clarke MA, Moore JL, Steege LM, Koopman RJ, Belden JL, et al. (2015) Health information needs, sources and barriers of primary care patients to achieve patient centered care: A literature review. Health Informatics J. 